\title{
Assessment, Evaluation, and Programming System for Infants and Children: What are Salient Development and Research Factors to Consider?
}

\author{
Marisa Macy ${ }^{1, *}$, Ching-I Chen ${ }^{2}$ and Robert Macy ${ }^{1}$ \\ ${ }^{1}$ University of Central Florida, USA \\ ${ }^{2}$ Kent State University, USA
}

\begin{abstract}
Early childhood professionals are increasingly pressed to use evidence-based measures when assessing young children. Professional time and resources to investigate research is limited, and takes time away from the delivery of direct services. The literature review is to describe the progression of a widely used curriculum-based assessment (CBA), the Assessment, Evaluation, and Programming System for Infants and Children (AEPS). In addition to sharing the development of this early childhood measure, we identified 19 studies from the available research found in various databases that have investigated the evidence supporting the use of this measure. Findings have implications for the validity, reliability, and utility of the AEPS.
\end{abstract}

Keywords: Assessment, Evaluation, and Programming System (AEPS), early childhood curriculum-based assessment, early intervention, early childhood special education, reliability, validity, utility.

The development and evidence supporting many measurement practices and tools are often imponderable. Assessment is the process of gathering information to make decisions [1]. Assessments provide information used to determine the developmental status, eligibility for early intervention (EI)/early childhood special education (ECSE) services, and accurate developmental and/or learning goals for young children and their families [2]. The Individuals with Disabilities Education Improvement Act [3] mandates the assessment of infants and toddlers for $\mathrm{El}$, as well as the assessment of preschoolers for ECSE. The IDEA supports that the assessment processes need to be developmentally appropriate, encourage family involvement, allow gathering relevant functional, developmental, and academic information about the child and family, as well as demonstrate improvements in child and family outcomes.

One curriculum-based instrument used by many early childhood providers that is well connected to the IDEA mandates is the Assessment, Evaluation, and Programming System for Infants and Children (AEPS) $[4,25]$. The AEPS contains an assessment that is linked to an accompanying early childhood curriculum for children birth to age six. The assessment tool measures child development via natural observations in familiar settings of children across six areas, including adaptive, cognitive, fine motor, gross motor,

Address correspondence to this article at the University of Central Florida, 4000 University BLVD, Orlando, FL 32816, USA; Tel: 407.823.6160; E-mail: Marisa.Macy@ucf.edu social, and social communication. AEPS has a family report that allows parents to report on their children's strengths and needs, enables collaboration between professionals and children's families, and can be used for progress monitoring.

To capture child changes, AEPS utilizes a graduated scoring mechanism (i.e., items, goals, and strands are arranged based on their developmental hierarchy). A three-point rating scale allows the user to determine the level of skill acquisition for a wide range of items. Mastery $=2$, emerging $=1$, or not yet $=0$. This assessment tool can be used as an initial assessment, as well as an evaluation showing growth over time. Furthermore, professionals are using AEPS to determine or corroborate eligibility for EI/ECSE [2, 5, 6]. AEPS also has an online data management component called the AEPS Interactive (AEPSi), to help monitor child progress and generate child outcome reports [7].

There are multiple editions of AEPS. Before AEPS was published by Paul Brookes Publishing Company it was called the Adaptive Performance Instrument (API) and the Evaluation Programming System: For Infants and Young Children (EPS) [4]. The API was field-tested and extensively revised based on feedback from users and data analysis results in the early 1970s. In the 1980s API was renamed as EPS to reflect the changes in items and curriculum. After the API and the EPS, the original AEPS was published by Brookes in 1993. The original AEPS contained two levels of test and associated curriculum: Birth to Three Years (Level I), and Three to Six Years (Level II). Additional research 


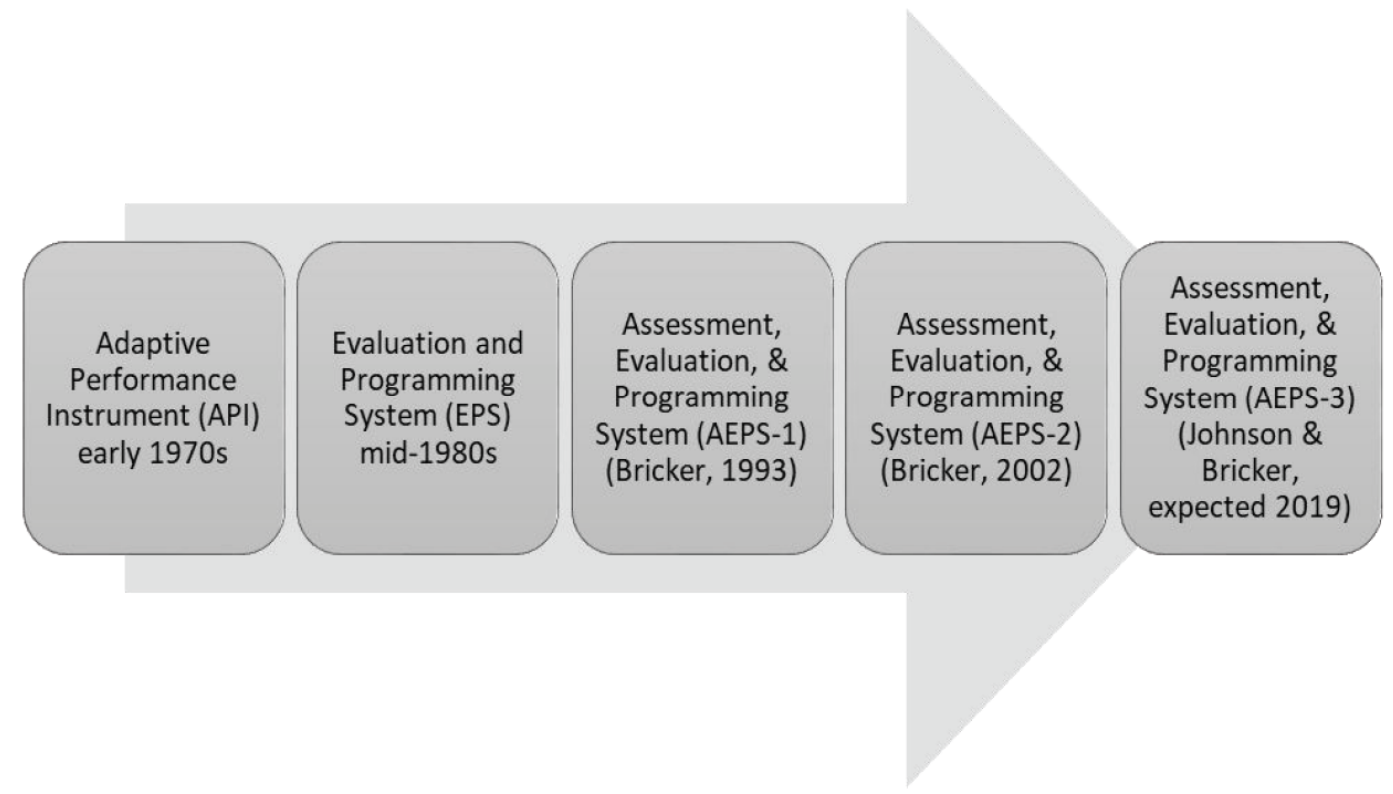

Figure 1: Timeline of multiple AEPS editions.

programs and outreach projects were then conducted to collect data and feedback for future revisions, as well as to ensure that field users accurately administer the test and implement the curriculum. In 2002, after content was expanded and additional changes were made to the test items and curriculum, the second edition was published.

AEPS third edition is currently in development and includes math and literacy as new areas, as well as a new component called the Ready Set that can be used by professionals to examine children's readiness during the transition from preschool into kindergarten settings. All of the six original AEPS areas have been revised in the third edition, as well as an entirely new curriculum framework. Figure 1 shows the editions of AEPS.

In this literature review, we intended to establish a research evidence base for the AEPS. Our three research questions are: (a) to what extent is the validity of AEPS supported in the literature, (b) to what extent is the reliability of AEPS supported in the literature, and (c) to what extent is the utility of AEPS supported in the literature?

\section{METHOD}

An examination of the extant literature for studies that included AEPS was conducted. First, we collected research studies related to our three research questions. Next, we reviewed the studies to determine inclusion in our research synthesis. Last, we analyzed the research studies to interpret findings. This section will describe the criteria used for selecting the studies, search terms, and search strategy. When searching for AEPS studies, we applied seven criteria to select studies for the research synthesis, including:

(1) study empirically investigated the English version of AEPS (all editions);

(2) AEPS was administered to a child from birth to age six;

(3) participants were children with/without disabilities or at-risk for developing a disability due to environmental or biological risk conditions;

(4) participants may also have included families who provided information about the assessment in the form of a survey or interview, and/or professionals who used the assessment;

(5) study was published in a peer-reviewed, scientific journal;

(6) study was published between 1980 and 2016; and

(7) study examined the validity, reliability, and/or utility of the AEPS.

The search was done covering the fields of education, special education, developmental disabilities, psychology, health, and social services. We identified AEPS studies using these search terms: early intervention, early childhood curriculum-based 
assessment, Assessment, Evaluation, and Programming System for Infants and Children Test, and AEPS. Terms used relating to earlier versions of AEPS include: Adaptive Performance Instrument (API) and Evaluation and Programming System: For Infants and Young Children (EPS). Technical reports and reviews, non-peer reviewed journal articles, and dissertation works were excluded.

The search procedures used in locating studies that fit the criteria were two-fold. First, we searched the professional literature using the university library system and electronic databases, including Academic Search Premier, ERIC, and PsycINFO. We also conducted hand searches of select journals. Second, we conducted an ancestral search. Once articles were found that matched the search criteria, references were used to further explore possible citations that might have been missed in the other search strategies.

A review team of at least two people read all of the articles that were included into the database. We used a coding protocol and database in Excel. We coded each article by indicating types of studies (e.g., reliability, validity, and/or utility), demographics, and other data that we have included in the tables. The plan was for researchers to review articles and then enter data into the Excel spreadsheet for each of AEPS research studies we found meeting criteria. If there was a disagreement, a plan was in place for a third qualified person to independently code the article and determine if it was appropriate to include in the database. Had

Table 1: AEPS Research Studies with Participant Demographic Information

\begin{tabular}{|c|c|c|c|c|}
\hline $\begin{array}{l}\text { Author(s) and Year } \\
\qquad(N=19)\end{array}$ & $\begin{array}{l}\text { Sample } \\
\text { Size }\end{array}$ & $\begin{array}{l}\text { Mean Age } \\
\text { in Months }\end{array}$ & $\begin{array}{l}\text { Age Range } \\
\text { in Months }\end{array}$ & Characteristics \\
\hline Bailey \& Bricker (1986) & 32 & $\mathrm{n} / \mathrm{a}$ & $\mathrm{n} / \mathrm{a}$ & $\begin{array}{c}\text { Children with and without typical } \\
\text { development }\end{array}$ \\
\hline Bricker, Bailey, \& Slentz (1990) & 335 & $\mathrm{n} / \mathrm{a}$ & 2 to 72 & $\begin{array}{c}\text { Children with and without typical } \\
\text { development }\end{array}$ \\
\hline Bricker et al. (2008) & 1,381 & $\mathrm{n} / \mathrm{a}$ & $\mathrm{n} / \mathrm{a}$ & $\begin{array}{l}\text { Children with }(n=719) \text { and without } \\
\text { typical }(n=662) \text { development }\end{array}$ \\
\hline Bricker, Yovanoff, Capt, \& Allen (2003) & 861 & $\mathrm{n} / \mathrm{a}$ & 1 to 72 & $\begin{array}{c}\text { Children with and without typical } \\
\text { development }\end{array}$ \\
\hline Gao \& Grisham-Brown (2011) & 32 & 58 & 40 to 64 & Children with typical development \\
\hline $\begin{array}{l}\text { Grisham-Brown, Hallam, \& Pretti-Frontczak } \\
\text { (2008) }\end{array}$ & 18 & $\mathrm{n} / \mathrm{a}$ & $\mathrm{n} / \mathrm{a}$ & Teachers from 9 inclusive classrooms \\
\hline $\begin{array}{l}\text { Hallam, Lyons, Pretti-Frontczak, \& Grisham- } \\
\text { Brown (2014) }\end{array}$ & 50 & 60.6 & 50 to 67 & $\begin{array}{l}\text { All had typical development prior to } \\
\text { AEPS and BDI-2 assessments }\end{array}$ \\
\hline Kim \& Sugawara (1998) & 20 & $\mathrm{n} / \mathrm{a}$ & $\mathrm{n} / \mathrm{a}$ & $\begin{array}{c}\text { Professionals of } 30 \text { children eligible for } \\
\text { ECSE }\end{array}$ \\
\hline Kim, Sugawara, \& Kim (2000) & 30 & $\mathrm{n} / \mathrm{a}$ & $\mathrm{n} / \mathrm{a}$ & $\begin{array}{l}\text { Parents of } 30 \text { children eligible for } \\
\text { ECSE }\end{array}$ \\
\hline Macy, Bricker, \& Squires (2005) & 68 & 27.7 & 6 to 36 & $\begin{array}{c}\text { Children with and without typical } \\
\text { development }\end{array}$ \\
\hline Macy \& Bricker (2007) & 3 & $\mathrm{n} / \mathrm{a}$ & 55 to 66 & Children eligible for ECSE \\
\hline Macy \& Macy (2016) & 15 & 53.8 & 28 to 66 & $\begin{array}{l}\text { Children with and without typical } \\
\text { development. }\end{array}$ \\
\hline Macy et al. (2015) & $\mathrm{n} / \mathrm{a}$ & $\mathrm{n} / \mathrm{a}$ & $\mathrm{n} / \mathrm{a}$ & No children. Expert panel of adults. \\
\hline Macy, Thorndike-Christ, \& Lin (2010) & 102 & $\mathrm{n} / \mathrm{a}$ & 6 to 36 & $\begin{array}{l}\text { Parents of } 74 \text { children with and } 28 \\
\text { children without typical development. }\end{array}$ \\
\hline Notari \& Bricker (1990) & 48 & $\mathrm{n} / \mathrm{a}$ & $\mathrm{n} / \mathrm{a}$ & $\begin{array}{c}\text { Professionals of children eligible for } \\
\text { EI/ECSE }\end{array}$ \\
\hline Notari \& Drinkwater (1991) & 31 & $\mathrm{n} / \mathrm{a}$ & 3 to 41 & $\begin{array}{l}\text { Children were at risk and with } \\
\text { disabilities }\end{array}$ \\
\hline Pretti-Frontczak \& Bricker (2000) & 86 & $\mathrm{n} / \mathrm{a}$ & 36 to 60 & $\begin{array}{c}\text { Professionals of preschoolers from } 5 \\
\text { states }\end{array}$ \\
\hline Rowe (2010) & 8 & $\mathrm{n} / \mathrm{a}$ & 24 to 60 & $\begin{array}{l}\text { Children with }(n=4) \text { and without } \\
\text { typical }(n=4) \text { development }\end{array}$ \\
\hline Wang, Sandall, Davis, \& Thomas (2011) & 22 & 56.5 & 36 to 76 & $\begin{array}{c}\text { Children with Autism Spectrum } \\
\text { Disorders }\end{array}$ \\
\hline
\end{tabular}


there been any disagreements we would have discussed until consensus was reached.

\section{RESULTS}

We found a total of 19 studies that met our criteria. Of the 19 peer-reviewed journal articles, fourteen were authored or co-authored by AEPS researchers. Results are then divided into four areas: (a) studies associated with AEPS before it became AEPS, (b) the original AEPS, (c) AEPS $2^{\text {nd }}$ edition, and (d) AEPS $3^{\text {rd }}$ edition.

Across all studies, researchers mostly utilized quantitative research methodology to study the validity, reliability, and utility of AEPS. Most studies used group designs, while one study used a single subject research design with three children [8]. A pre/posttest using AEPS-3 early literacy curriculum and assessment was another type of research design for example [9]. Table 1 shows demographic information about participants in both published research studies.

\section{PUBLISHED AND PEER-REVIEWED STUDIES}

A total of 19 studies were found on AEPS that were published in academic, peer-reviewed journals that met our criteria. Results are reported across different versions of AEPS (see Table 2). Studies explored topics related to validity, reliability, and utility.

\section{Table 2: Results from AEPS Studies}

\begin{tabular}{|c|c|}
\hline $\begin{array}{l}\text { Author(s) and Year } \\
\qquad(N=19)\end{array}$ & Reported Results \\
\hline Bailey \& Bricker (1986) & This study showed administration of the AEPS could be accomplished in a timely manner. \\
\hline $\begin{array}{l}\text { Bricker, Bailey, \& Slentz } \\
\text { (1990) }\end{array}$ & $\begin{array}{l}\text { Results showed strong test-retest reliability (.84- } .96) \text {, Interrater reliability }(.85-.96) . \text { Internal consistency } \\
(.60-.95) \text {, and congruent validity }(.50-.93) \text { of the AEPS. }\end{array}$ \\
\hline Bricker et al. (2008) & $\begin{array}{l}\text { The AEPS generally performed well in terms of measurement reliability. The sensitivity of the AEPS cutoff } \\
\text { scores for both levels was consistently moderate to high, and the specificity rates were less robust. }\end{array}$ \\
\hline $\begin{array}{l}\text { Bricker, Yovanoff, Capt, \& } \\
\text { Allen (2003) }\end{array}$ & $\begin{array}{l}\text { The AEPS cutoff scores from the } 2^{\text {nd }} \text { edition could be used to accurately identified children with } \\
\text { delays/disabilities. }\end{array}$ \\
\hline Gao \& Grisham-Brown (2011) & $\begin{array}{l}\text { There was a statistically significant, positive correlation between the AEPS social-communication area } \\
\text { score and the BDI-2 communication domain score and between the cognitive domains of both tests. } \\
\text { Teacher considered the AEPS a useful tool for planning classroom instructional }\end{array}$ \\
\hline $\begin{array}{l}\text { Grisham-Brown, Hallam, \& } \\
\text { Pretti-Frontczak (2008) }\end{array}$ & After receiving training, Head Start teachers could reliably assess preschoolers with the AEPS. \\
\hline $\begin{array}{l}\text { Hallam, Lyons, Pretti- } \\
\text { Frontczak, \& Grisham-Brown } \\
\qquad(2014)\end{array}$ & $\begin{array}{l}\text { The AEPS and the BDI- } 2 \text { had reached agreement on assessment results (i.e., the determination of a } \\
\text { child's developmental status) for } 78 \% \text { of the sample. }\end{array}$ \\
\hline Kim \& Sugawara (1998) & $\begin{array}{l}\text { Activity-based assessment was superior to traditional standardized instrument in the areas of measuring } \\
\text { functional skills, parent satisfaction, and providing useful assessment information for intervention planning. }\end{array}$ \\
\hline Kim, Sugawara, \& Kim (2000) & $\begin{array}{l}\text { Activity-based assessment allowed more active parent involvement, provided more information to parents } \\
\text { and used more age-appropriate activities to measure children's skills. }\end{array}$ \\
\hline $\begin{array}{l}\text { Macy, Bricker, \& Squires } \\
\text { (2005) }\end{array}$ & $\begin{array}{l}\text { Strong sensitivity (100\%) and specificity (89\%) were observed for using the AEPS to determine eligibility } \\
\text { for EI/ECSE. }\end{array}$ \\
\hline Macy \& Bricker (2007) & $\begin{array}{l}\text { The AEPS could be used as the outcome measure for embedding learning opportunities on social goals } \\
\text { and demonstrated progress. }\end{array}$ \\
\hline Macy \& Macy (2016) & $\begin{array}{l}\text { Preschoolers in inclusive classes were assessed using early literacy games and playful activities to assess } \\
\text { their early literacy skills from AEPS early literacy items from the third edition. Results showed AEPS-3 } \\
\text { items are helpful in assessing children with disabilities, at risk, and with typical development. }\end{array}$ \\
\hline Macy et al. (2015) & The feedback from the expert panel helped refine AEPS-3 items and improve content validity of AEPS-3. \\
\hline $\begin{array}{l}\text { Macy, Thorndike-Christ, \& Lin } \\
(2010)\end{array}$ & $\begin{array}{l}\text { Authentic assessment (e.g., the AEPS) was more favorably rated in parent satisfaction and } \\
\text { appropriateness for children when comparing to traditional standardized instrument. }\end{array}$ \\
\hline Notari \& Bricker (1990) & $\begin{array}{l}\text { Early interventionist who used the AEPS or received AEPS training wrote higher quality goals/objectives } \\
\text { than a comparison group that used other assessment tools. }\end{array}$ \\
\hline Notari \& Drinkwater (1991) & $\begin{array}{l}\text { Teachers who used the AEPS or received AEPS training wrote significantly higher quality goals and } \\
\text { objectives (e.g., more functional, measurable, and teachable). }\end{array}$ \\
\hline $\begin{array}{l}\text { Pretti-Frontczak \& Bricker } \\
(2000)\end{array}$ & $\begin{array}{l}\text { Results indicated the quality of written IEP goals and objectives improved following the training and use of } \\
\text { the AEPS }\end{array}$ \\
\hline Rowe (2010) & $\begin{array}{l}\text { The AEPS was able to serve as an outcome measure for examining play differences between children } \\
\text { with and without disabilities. }\end{array}$ \\
\hline $\begin{array}{l}\text { Wang, Sandall, Davis, \& } \\
\text { Thomas (2011) }\end{array}$ & $\begin{array}{l}\text { AEPS had high internal consistency with PKBS and SSRS, with a high correlation between the social } \\
\text { domains of the AEPS and the PKBS and SSRS. }\end{array}$ \\
\hline
\end{tabular}

Note BDI = Battelle Developmental Inventory; PKBS = Preschool and Kindergarten Behavior Scale; SSRS = Social Skills Rating Scale; IFSP = Individual Family Service Plan; EI/ECSE = Early Intervention/Early Childhood Special Education. 


\section{By AEPS Edition}

In the next four sections, the results for each edition of AEPS (i.e., pre-, 1, 2, and 3) are presented. Results reported are across psychometric characteristics.

\section{Pre-AEPS}

There were four reliability and validity studies associated with AEPS before it became the AEPS. Bailey and Bricker [10] and Bricker, Bailey, and Slentz [11] conducted research on the birth to three age range of EPS from 1984 to 1987. Notari and Bricker [12] were the first team to investigate treatment validity and how well the tool could be used to create high quality IEP/IFSP goals. Notari and Drinkwater [13] also investigated goal development. Results for published and peer-reviewed pre-AEPS studies are shown in Table 3a.

\section{The Original AEPS}

The first published edition of AEPS [14] contains three published utility studies $[15,16,17]$. Research examined how useful AEPS is in creating IEP/IFSP goals and objectives, as well as consumer satisfaction. Results for published and peer-reviewed AEPS-1 studies are shown in Table $\mathbf{3 b}$.

\section{The AEPS $2^{\text {nd }}$ Edition}

All ten studies on the second edition of AEPS [4] were validity studies. Four or $40 \%$ of the studies examined the concurrent validity of AEPS and the BDI$2[18,19,6,20]$. The study by Wang et al. [20] explored the reliability of AEPS items and resulted in a Cronbach's alpha of .98 . Reliability of the AEPS to determine eligibility, or corroborate eligibility determination, for El/ECSE was examined in three research studies. Results ranged between .59-.97 [21,

Table 3a: Types of Reliability and Validity in Published Pre-AEPS Research Studies

\begin{tabular}{|c|c|c|c|c|c|c|c|c|}
\hline \multirow[b]{2}{*}{$\begin{array}{l}\text { Author(s) and Year } \\
\text { ( } n=4 \text { studies) }\end{array}$} & \multirow[b]{2}{*}{ Test } & \multicolumn{3}{|c|}{ Reliability } & \multicolumn{4}{|c|}{ Validity } \\
\hline & & $\begin{array}{l}\text { Inter- } \\
\text { rater }\end{array}$ & $\begin{array}{l}\text { Test- } \\
\text { retest }\end{array}$ & $\begin{array}{c}\text { Internal } \\
\text { consistency }\end{array}$ & $\begin{array}{l}\text { Sensitivity }^{a} \\
\text { Specificity }^{b}\end{array}$ & Concurrent & Content & Utility \\
\hline Bailey \& Bricker (1986) & $\begin{array}{c}\text { Pre- } \\
\text { AEPS } \\
\text { (EPS) }\end{array}$ & $x^{b}$ & $x$ & & & $x$ & & $x$ \\
\hline Bricker, Bailey, \& Slentz (1990) & $\begin{array}{c}\text { Pre- } \\
\text { AEPS } \\
\text { (EPS) }\end{array}$ & $x^{b}$ & $x$ & $x$ & & $x$ & & $x$ \\
\hline Notari \& Bricker (1990) & $\begin{array}{c}\text { Pre- } \\
\text { AEPS } \\
\text { (EPS), } \\
\text { Gesell, } \\
\text { GORI }\end{array}$ & & & & & & & $x$ \\
\hline Notari \& Drinkwater (1991) & $\begin{array}{c}\text { Pre- } \\
\text { AEPS } \\
\text { (EPS), } \\
\text { GORI }\end{array}$ & & & & & & & $x$ \\
\hline
\end{tabular}

Note. The following abbreviations were used for Test column: Pre-AEPS = studies conducted on the earliest versions of the AEPS called the Evaluation and Programming System (EPS); GORI = Goals and Objective Rating Inventory.

Table 3b: Types of Reliability and Validity in Published AEPS-1 Research Studies

\begin{tabular}{|c|c|c|c|c|c|c|c|c|}
\hline \multirow[b]{2}{*}{$\begin{array}{l}\text { Author(s) and Year } \\
\qquad(n=3 \text { studies) }\end{array}$} & \multirow[b]{2}{*}{ Test } & \multicolumn{3}{|c|}{ Reliability } & \multicolumn{4}{|c|}{ Validity } \\
\hline & & $\begin{array}{l}\text { Inter- } \\
\text { rater }\end{array}$ & $\begin{array}{l}\text { Test- } \\
\text { retest }\end{array}$ & $\begin{array}{c}\text { Internal } \\
\text { consistency }\end{array}$ & $\begin{array}{l}\text { Sensitivity }^{a} \\
\text { Specificity }^{b}\end{array}$ & Concurrent & Content & Utility \\
\hline Kim \& Sugawara (1998) & $\begin{array}{c}\text { AEPS-1 } \\
\text { BDI }\end{array}$ & & & & & & & $x$ \\
\hline Kim, Sugawara, \& Kim (2000) & $\begin{array}{c}\text { AEPS-1 } \\
\text { BDI }\end{array}$ & & & & & & & $x$ \\
\hline Pretti-Frontczak \& Bricker (2000) & $\begin{array}{l}\text { AEPS-1, } \\
\text { GORI }\end{array}$ & & & & & & & $x$ \\
\hline
\end{tabular}

Note. The following abbreviations were used for Test column: AEPS-1 = first edition; GORI = Goals and Objective Rating Inventory. 
Table 3c: Types of Reliability and Validity in Published AEPS-2 Research Studies

\begin{tabular}{|c|c|c|c|c|c|c|c|c|}
\hline \multirow[b]{2}{*}{$\begin{array}{l}\text { Author(s) and Year } \\
\qquad(n=10 \text { studies) }\end{array}$} & \multirow[b]{2}{*}{ Test } & \multicolumn{3}{|c|}{ Reliability } & \multicolumn{4}{|c|}{ Validity } \\
\hline & & $\begin{array}{l}\text { Inter- } \\
\text { rater }\end{array}$ & $\begin{array}{l}\text { Test- } \\
\text { retest }\end{array}$ & $\begin{array}{c}\text { Internal } \\
\text { consistency }\end{array}$ & $\begin{array}{l}\text { Sensitivity }^{a} \\
\text { Specificity }^{b}\end{array}$ & Concurrent & Content & Utility \\
\hline Bricker et al. (2003) & AEPS-2 & & & & $\begin{array}{l}x^{a} \\
x^{b}\end{array}$ & & & \\
\hline Bricker et al. (2008a) & AEPS-2 & & & & $\begin{array}{l}x^{a} \\
x^{b}\end{array}$ & & & \\
\hline Gao \& Grisham-Brown (2011) & $\begin{array}{l}\text { AEPS-2 } \\
\text { BDI-2 }\end{array}$ & & & & & $x$ & & $x$ \\
\hline $\begin{array}{c}\text { Grisham-Brown, Hallam, \& } \\
\text { Pretti-Frontczak (2008) }\end{array}$ & AEPS-2 & & & & & & & $x$ \\
\hline Hallam et al. (2014) & $\begin{array}{l}\text { AEPS-2 } \\
\text { BDI-2 }\end{array}$ & & & & & $x$ & & \\
\hline Macy \& Bricker (2007) & AEPS-2 & & & & & & & $x$ \\
\hline Macy, Bricker, \& Squires (2005) & $\begin{array}{c}\text { AEPS-2 } \\
\text { BDI-2 }\end{array}$ & $x^{b}$ & & & $\begin{array}{l}x^{a} \\
x^{b}\end{array}$ & $x$ & & \\
\hline Macy et al. (2010) & AEPS-2 & & & & & & & $x$ \\
\hline Rowe (2010) & $\begin{array}{c}\text { AEPS-2, } \\
\text { Play } \\
\text { Group } \\
\text { Scale }\end{array}$ & & & & & & & $\mathrm{x}$ \\
\hline Wang et al. (2011) & $\begin{array}{l}\text { AEPS-2, } \\
\text { SSRS, } \\
\text { PKBS }\end{array}$ & & & $\mathrm{x}$ & & $x$ & $\mathrm{x}$ & \\
\hline
\end{tabular}

Note. The following abbreviations were used for Test column: AEPS-2 = second edition; BDI = Battelle Developmental Inventory; PKBS $=$ Preschool and Kindergarten Behavior Scale; SSRS = Social Skills Rating Scale.

Table 3d: Types of Reliability and Validity in Published AEPS-3 Research Studies

\begin{tabular}{|c|c|c|c|c|c|c|c|c|}
\hline \multirow[b]{2}{*}{$\begin{array}{l}\text { Author(s) and Year } \\
\qquad(n=2 \text { studies) }\end{array}$} & \multirow[b]{2}{*}{ Test } & \multicolumn{3}{|c|}{ Reliability } & \multicolumn{4}{|c|}{ Validity } \\
\hline & & $\begin{array}{l}\text { Inter- } \\
\text { rater }\end{array}$ & $\begin{array}{l}\text { Test- } \\
\text { retest }\end{array}$ & $\begin{array}{c}\text { Internal } \\
\text { consistency }\end{array}$ & $\begin{array}{l}\text { Sensitivity }^{a} \\
\text { Specificity }^{b}\end{array}$ & Concurrent & Content & Utility \\
\hline Macy \& Macy (2016) & AEPS-3 & & & & & & $x$ & \\
\hline Macy et al. (2015) & AEPS-3 & & & & & & $x$ & \\
\hline
\end{tabular}

Note. AEPS-3 = third edition (experimental version).

2, 6]. Five studies included utility into the research design to examine various aspects of how useful AEPS is to professionals and parents [18, 22, 8, 23, 24]. AEPS-2 studies are shown in Table $3 c$.

\section{The AEPS $3^{\text {rd }}$ Edition}

Two validity studies were published related to an experimental version of the third edition of AEPS [25]. Two studies sought to examine the content validity of AEPS. A study published in 2015 by authors of AEPS- 3 used an expert panel to review AEPS items and used qualitative feedback to modify items, developmental sequences and area content [26]. In general, AEPS items addressed critical developmental milestones and followed appropriate developmental sequences. Nonetheless, some reviewers from the expert panel reflected on how certain examples were too specific to "western culture" and needed to be revised.

The other study specifically examined the quality and functionality of items in the early literacy area of the third edition. Results from this study showed that AEPS-3 items are helpful in assessing children with disabilities, at risk, and with typical development in the area of early literacy [9]. Both of these studies occurred prior to publication of the third edition. Results for 
published and peer-reviewed AEPS-3 studies are shown in Table $\mathbf{3 d}$.

\section{DISCUSSION}

Programmatic assessments are widely used in early childhood professional practices with young children for a variety of purposes [1]. This study sought to synthesize the available research on a curriculumbased instrument. The AEPS editions were summarized separately to delineate the various versions. We included multiple editions so the reader could determine how AEPS has evolved over time. Literature reviewed showed AEPS could be used with both typically developing children and children with special needs between the ages of birth to six years. Findings demonstrated that AEPS is an instrument with adequate technical adequacy.

\section{Validity}

In general, the available evidence for each edition suggested AEPS is a valid tool that can measure what it intends to measure - general development of young children. Results from the studies of each edition (i.e., EPS, AEPS-1, and AEPS-2) indicated that overall AEPS demonstrated strong construct validity, and moderate to strong and positive correlations with different criterion measures between their total scores or domain scores.

Weaker correlation has been reported between AEPS and other criterion measures in the earlier version $[10,11]$ but AEPS-2 was moderately or strongly related to the criterion measures in different developmental domains [21, 20]. For example, in the study conducted by Wang et al. [20] on AEPS-2, the social domain of AEPS had a high correlation with the Social Skills Rating Scale, and the Preschool and Kindergarten Behavior Scale. The AEPS also demonstrated solid content validity based on the research evidence collected.

\section{Reliability}

In general, the research evidence suggested that AEPS results are consistent and reliable $[1,11,6]$. Results coming from different editions indicated that in general items in each of AEPS areas (e.g., social communication, adaptive) are closely related to each other.

\section{Utility}

AEPS is used to address the needs of children from multiple areas. Practitioners and families considered
AEPS a professional and family friendly tool. For example, in a study conducted by Gao and GrishamBrown [18], the five teachers participated in the focus group reported that AEPS) elicits natural responses of young children and allows parental involvement. Teachers also indicated that they used results to inform their classroom instruction.

Additionally, AEPS was designed to contain desirable practice characteristics such as functional content, comprehensive coverage (across and within domains), graduated scoring (i.e., 3-point rating scale with qualifying notes), procedural flexibility, and the standardization sample includes children with disabilities [27]. In multiple studies [18, 12, 13, 17], AEPS was reported a useful tool for developing individualized and functional EI/ECSE goals for an IEP or IFSP. For example, in the Pretti-Frontczak and Bricker [17] study, the 86 participants made significant improvements after receiving training on using AEPS information to write IEP goals and objectives.

In general, results indicated that practitioners and families consider the assessment information provided by AEPS helpful and pertinent to support daily functioning of children. Additionally, with training, AEPS practitioners can write quality IFSP and/or goals.

\section{Evolution Across Editions}

Across different editions, the underlying philosophy and structure of AEPS has not changed significantly. AEPS is developed to provide a curriculum-based and linked system that allows professional to actively involve parents in collecting developmental information via natural observations, planning interventions and monitoring progress of learning daily functional skills with parents in natural environments. This is evident across utility studies of different AEPS editions.

Changes that have occurred across the various editions are item additions and revisions, scoring options, and the inclusion of two new areas (i.e., math and literacy) with AEPS-3 edition. One major revision is that the assessment and curriculum of earlier editions had two age bands: (a) birth to three, and (b) three to six. AEPS-3 will have one combined scale from birth to age six with no separation. Of each edition, results from the publications that examined psychometric properties and utility informed the revision of the next edition. For example, even though the dissertation conducted by Kim [28] was not included in this literature review, this dissertation study researched the 
possibility of using an activity-based assessment (i.e., AEPS-1) to determine eligibility. When comparing to a standardized, diagnostic assessment tool (i.e., BDI), AEPS was preferred by interventionists and families due to its ability in measuring functional skills and providing meaningful information for intervention planning. This served as the foundation for subsequent studies that examines using AEPS-2 for eligibility determination $[2,6]$ and eventually led to the development of AEPS-2 cutoff scores [5, 21].

The findings of this study should be interpreted with two limitations in mind. First, the criteria for inclusion in this research synthesis was limited to studies written and published in English. Other research studies may exist that are written and published in languages other than English. Second, some of the studies were conducted and written for publication by the authors of AEPS. We report here the available research we found in our databases using the search terms we generated. There may be other AEPS studies we did not find in our investigation, or that did not meet our criteria for inclusion.

Future directions in research on AEPS could focus on: (1) increasing cultural and linguistic diversity, and (2) conducting field testing on the third edition (which is currently underway) to examine its validity, reliability, and utility. Even though AEPS items and examples are flexible for adaptations, and a study has been conducted to use feedback from an expert panel to refine items in the third edition [26], cultural and linguistic studies can be conducted to further understand how AEPS can address the needs of a diverse population of children and their families. Also, additional field test studies should be conducted to provide solid research evidence on technical adequacy, especially on the two newly added areas, early literacy and early numeracy.

Development and research factors were considered regarding the AEPS. This research synthesis provides a resource for early childhood assessment consumers about one CBA. More studies on AEPS and other CBAs can be useful for busy professionals who may not have the time or resources to conduct their own such research in synthesizing evidence-based measures.

\section{REFERENCES}

[1] Bagnato SJ, Neisworth JT, Pretti-Frontczak K. LINKing authentic assessment and early childhood intervention: Best measures for best practice. 2nd ed. Baltimore: Brookes; 2010.
[2] Bricker D, Yovanoff P, Capt B, Allen D. Use of a curriculumbased measure to corroborate eligibility decisions. Journal of Early Intervention 2003; 26: 20-30.

https://doi.org/10.1177/105381510302600102

[3] Individuals with Disabilities Education Act 2004; 20 U.S.C. §§ 1400-1482.

[4] Bricker, D. Assessment, evaluation, and programming system for infants and children. $2^{\text {nd }}$ ed. Baltimore: Brookes; 2002.

https://doi.org/10.1037/t11481-000

[5] Bricker D, Clifford J, Yovanoff P, Pretti-Frontczak K, Waddell $\mathrm{M}$, Allen D, Hoselton R. Eligibility determination using a curriculum-based assessment measure: A replication study. Journal of Early Intervention 2008; 31: 3-21. https://doi.org/10.1177/1053815108324422

[6] Macy MG, Bricker DD, Squires JK. Validity and reliability of a curriculum-based assessment approach to determine eligibility for part $\mathrm{C}$ services. Journal of Early Intervention 2005; 28: 1-16.

https://doi.org/10.1177/105381510502800101

[7] Macy M. Interactive online assessment options: A review of the AEPSi. International Journal of Early Childhood Special Education 2010; 2: 254-7. https://doi.org/10.20489/intjecse.107973

[8] Macy M, Bricker D. Embedding individualized social goals into routine activities in inclusive early childhood classrooms. Early Child Development \& Care 2007; 177: 107-20. https://doi.org/10.1080/03004430500337265

[9] Macy M, Macy RS. Playing to win: A model using games for early literacy assessment. New Mexico Journal of Reading 2016; 36: 6-11.

[10] Bailey E, Bricker D. A psychometric study of a criterionreferenced assessment designed for infants and young children. Journal of the Division of Early Childhood 1986; 10 : 124-134. https://doi.org/10.1177/105381518601000204

[11] Bricker D, Bailey E, Slentz K. Reliability, validity, and utility of the evaluation and programming system: For infants and young children (EPS-I). Journal of Early Intervention 1990; 14: 147-160. https://doi.org/10.1177/105381519001400204

[12] Notari A, Bricker D. The utility of a curriculum-based assessment instrument in the development of individualized education plans for infants and young children. Journal of Early Intervention 1990; 14: 117-132. https://doi.org/10.1177/105381519001400202

[13] Notari A, Drinkwater S. Best practice for writing child outcomes: An evaluation of two methods. Topics in Early Childhood Special Education 1991; 11: 92-106. https://doi.org/10.1177/027112149101100309

[14] Bricker, D. Assessment, evaluation, and programming system for infants and children. $1^{\text {st }}$ ed. Baltimore: Brookes; 1993.

[15] Kim YM, Sugawara AI. Perceptions of early childhood special education professionals: Assessment of functional skills among children with special needs. Early Child Development and Care 1998; 146: 33-40. https://doi.org/10.1080/0300443981460104

[16] Kim YM, Sugawara Al, Kim G. Parents' perception of and satisfaction with the eligibility assessment of their children with special needs. Early Child Development and Care 2000; 160: 133-142. https://doi.org/10.1080/0030443001600112

[17] Pretti-Frontczak P, Bricker D. Enhancing the quality of Individualized Education Plan (IEP) goals and objectives. Journal of Early Intervention 2000; 23: 92-105. https://doi.org/10.1177/105381510002300204

[18] Gao X, Grisham-Brown J. The use of authentic assessment to report accountability data on young children's language, 
literacy and pre-math competency. International Educational Studies 2011; 4: 41-53.

https://doi.org/10.5539/ies.v4n2p41

[19] Hallam R, Lyons A, Pretti-Frontczak K, Grisham-Brown J. (2014). Comparing apples and oranges: The mismeasurement of young children through the mismatch of assessment purpose and the interpretation of results. Topics in Early Childhood Special Education, 2014; 34: 106-115. https://doi.org/10.1177/0271121414524283

[20] Wang H, Sandall S, Davis C, Thomas C. Social skills assessment in young children with autism: A comparison evaluation of the SSRS and PKBS. Journal of Autism \& Developmental Disorders 2011; 41: 1487-1495. https://doi.org/10.1007/s10803-010-1175-8

[21] Bricker D, Clifford J, Yovanoff P, Waddell M, Allen D, PrettiFrontczak K, \& Hoselton R. Deriving and using the AEPS cutoff scores to assist in determining eligibility for services. 2008.

https://doi.org/10.1177/1053815108324422

[22] Grisham-Brown J, Hallam R, Pretti-Frontczak K. Preparing Head Start personnel to use a curriculum-based assessment an innovative practice in the "age of accountability." Journal of Early Intervention 2008; 30: 271-281. https://doi.org/10.1177/1053815108320689

[23] Macy M, Thorndike-Christ T, Lin Y. Parental reports of perceived assessment utility: A comparison of authentic and conventional approaches. Infants \& Young Children 2010; 23: 286-302.

https://doi.org/10.1097//YC.0b013e3181f1ec1b

[24] Rowe M. Shaving cream and cowboys: A descriptive study of play differences between typically developing and developmentally delayed preschoolers. Education Research \& Perspectives 2010; 37: 64-78.

[25] Johnson J, Bricker D, Eds. Assessment, evaluation, and programming system for infants and children $3^{\text {rd }}$ ed. Baltimore: Brookes in progress.

[26] Macy M, Bricker D, Dionne C, Grisham-Brown J, Waddell M, Slentz K, Johnson J, Behm M, Shrestha H. Content validity analyses of qualitative feedback on the revised Assessment, Evaluation, \& Programming System for infants and children (AEPS) test. Journal of Intellectual Disability: Diagnosis and Treatment 2015; 3: 177-186. https://doi.org/10.6000/2292-2598.2015.03.04.3

[27] Macy M, Bagnato S. Keeping it "R-E-A-L" with authentic assessment. National Head Start Association Dialog 2010; 13: 1-21. https://doi.org/10.1080/15240750903458105

[28] Kim YM. An activity-based assessment: A functional approach to determining eligibility of young children. Unpublished doctoral dissertation. University of Oregon: Eugene; 1996.

\section{DOI: https://doi.org/10.6000/2292-2598.2019.07.03.2}

(C) 2019 Macy et al.; Licensee Lifescience Global.

This is an open access article licensed under the terms of the Creative Commons Attribution Non-Commercial License (http://creativecommons.org/licenses/by-nc/3.0/) which permits unrestricted, non-commercial use, distribution and reproduction in any medium, provided the work is properly cited. 